\title{
Martyna Jaskulska
}

Uniwersytet Gdański

szadar@wp.pl

\section{Marta Lockiewicz}

Uniwersytet Gdański

psymlo@univ.gda.pl

\section{Polish as L1, English as L2: the linguistic transfer impact on Second Language Acquisition stemming from the interlingual differences: implications for young learners education}

\begin{abstract}
Summary
Research has shown that learners of different linguistic backgrounds make similar errors, which is due to linguistic transfer. Cross-linguistic similarities between L1 and L2 can result in: positive transfer, negative transfer, and differing lengths of acquisition. The bigger the difference between the languages, the bigger Second Language Acquisition difficulties and more numerous potential negative transfer areas. This effect is visible in the case of Polish as L1 and English as L2. English and Polish differ in terms of pronunciation (e.g. vowel-based vs. consonant-based), spelling (e.g. opaque vs. semi-transparent), grammar (e.g. fixed vs. flexible word order), syntax (e.g. analytic vs. synthetic), and vocabulary. Therefore, second language instruction should include the errors caused by linguistic transfer, which would facilitate the selection and development of effective instruction methods and techniques.
\end{abstract}

Słowa kluczowe: angielski jako język obcy, polski jako L1, transfer językowy, przejrzystość języka, nabywanie języka obcego

Keywords: English as a foreign language, Polish as L1, linguistic transfer, language transparency, SLA

\section{Introduction}

According to the Education and Training 2020 strategy (Eurydice 2005), pupils should be taught two foreign languages from an early age. Poland follows these recommendations, as children learn English starting from the reception year, and from year 2017/2018 starting from kindergarten (Journal of Laws of 2014, item 803). In early SL (second language) education, the aims of teaching include building positive motivation, exposure to foreign speech, and creating bases for systematic linguistic work (Komorowska 2009). Cummins (1991) assumes that Second Language Acquisition (SLA) depends on attribute-based (cognitive skills and 
personality) and input-based (the quality and quantity of a foreign language input) aspects of linguistic proficiency. In this paper, we will focus on the difficulties regarding the input-based influences: the linguistic transfer impact on SLA stemming from the differences between Polish as a mother tongue (L1) and English as a second, foreign language (L2). We aim to characterize the syntax, morphology, phonetics, phonology, and orthography of Polish and English, putting specific emphasis on the differences that can result in certain errors. Basing on the analysis of literature and students' original performance, these errors will be listed, and the implications for educational practice discussed. As young learners demonstrate certain skills and relative ease of progress in SLA, a proper teaching strategy that takes into account the typical errors made by Polish students can prevent them from acquiring typical patterns of errors.

\section{Comparison of syntax and morphology}

In our compared pair of languages only English has articles, and its syntax is more uniform. All affirmative sentences follow the SVO pattern (the order of words indicates their syntactic function) (Doroszewski, Wieczorkiewicz 1972), inversion characterizes most questions, and no double negation appears. Polish allows for greater flexibility; the SVO pattern is preferable, but optional, as the morphological structure of a word (suffixes and inflections: declension and conjugation) indicates its syntactic function (Polański, Nowak 2011). Sentences can contain the implied subject, and double or even triple or more negations are used.

Morphologically, English is an analytical language with tenses to conjugate verbs. Fromkin and Rodman (1993) list eight inflectional morphemes: 1. -s - third person singular present; 2. -ed - past tense; 3. -ing - progressive; 4. -en - past participle; 5. -s - plural; 6. -'s - possessive (genitive); 7. -er - comparative; 8. -est - superlative. In Polish, a synthetic language, nouns can be animate and inanimate, inflected by suffixes in singular and plural in congruence with grammatical genders - masculine, feminine, and neuter (in plural - masculine-personal and nonmasculine-personal) (Porayski-Pomsta, Podracki 1996). Seven cases in Polish: Nominative, Genitive, Dative, Accusative, Ablative (Instrumental), Locative, and Vocative lead to 5 declension types of singular masculine nouns, 6 of singular neuter nouns, 6 of singular feminine nouns, and 2 declension types of nouns which have only plural form (Tokarski 1978). Adjectives, pronouns, and numerals must be declined accordingly to show their grammatical relationship with other words in a sentence.

Moreover, in Polish verbs must be conjugated in terms of the grammatical gender of a speaker, persons, plurality, tense, with subject-verb concordance. Verbs can be perfective or imperfective, active or passive, and can have a form of a statement, imperative or conditional. Tokarski (1978) lists 11 conjugation groups of verbs, depending on the ending morpheme. Adverbs, interjections, prepositions, conjunctions, and particles are the uninflected parts of speech.

Borrowings from English to Polish include: 'jacht' ('yacht'), or 'rum' ('rum'). Polish is richer than English in word formation due to richer morphology and inflexion. Numerous diminutives and augmentatives can be formed, and Polish words are, on average, longer. 
Teachers should clearly indicate the importance of the fixed word order in English, as students tend to produce sentences following Polish syntactic rules (often as a result of a word-for-word translation), at the expense of both grammar and meaning. To prevent this habit, students should practise repetitively certain frequent structures in reading, writing, and oral communication with each other and the teacher to reinforce correct patterns. Additionally, differences between specific Polish and English rules should be emphasised.

\section{Comparison of phonetics and phonology}

In the International Phonetic Alphabet (IPA), out of 44 phonemes in RP English ${ }^{1}$ (Milewski 1999), 20 are constituted by different vowels (12 monophthongs and 8 diphthongs), formed by only 6 letters: a, e, i, o, u, y (Forel \& Puskas 2005). In Polish, 40 (Malczewski 1990), or 39 (Milewski 1999) phonemes are listed, depending on a researcher's approach to the realisation of some phonemes; 8 vowels occur.

In English (Forel, Puskas 2005) ${ }^{2}$ consonants are divided due to:

- voicing - voiced /ð/, voiceless $/ \theta /$;

- place of articulation - bilabial $/ \mathrm{m} /$, labiodental $/ \mathrm{v} /$, dental $/ \mathrm{d} /$, alveolar $/ \mathrm{r} /$, palatoalveolar $/ \mathrm{t} \mathrm{f} /$, palatal $/ \mathrm{j} /$, velar $/ \mathrm{y} /$, glottal $/ \mathrm{h} /$;

- manner of articulation:

a) obstruents: plosives $/ \mathrm{p} /$, fricatives /ff/, affricates $/ \mathrm{t} \mathrm{f}$,

b) sonorants: nasals $/ \mathrm{m} /$, lateral $/ 1 /$, approximants $/ \mathrm{r} /$.

Vowels are divided due to:

- tongue position - high /i:/, mid /e/, low /æ/, front / $/$, central /a/, back /u:/,

- length - long $/ 3: /$, short $/ \mathrm{p} /$,

- rounding - open $/ \mathrm{a} /$, close $/ \mathrm{u} /$,

- diphthongs $-/$ เə/.

In Polish (Ryndak 2014) consonants are divided due to:

- position of the speech apparatus - approximant $/ \mathrm{j} /$, fricative $/ 6 /$, affricative $/ \mathrm{t}_{6} /$, plosive $/ \mathrm{p} /$,

- place of articulation - bilabial $/ \mathrm{m} /$, labio-dental $/ \mathrm{f} /$, dental /ts $/$, alveolar $/ \mathrm{tg} /$, alveolopalatal $/ 6 /$, palatal $/ \mathrm{j} /$, velar $/ \mathrm{x} /$,

- vocal folds participation - voiced /d/ and voiceless /t/,

- nasal resonance participation - nasal $/ \mathrm{m} /$, oral $/ 1 /$.

Vowels are divided due to:

- vertical tongue movements - high $/ \mathrm{i} /$, intermediate $/ \tilde{\varepsilon} /$, low $/ \mathrm{a} /$,

- horizontal tongue movements - front / $/$ /, central/a/, back / $\tilde{\mathrm{o}} /$,

- soft palate movements - oral /u/, nasal / $\tilde{\varepsilon} /$,

- lips movements - round /o/, neutral /a/, flat /i/.

RP is the standard version of British English typically taught in Polish kindergartens and schools.

2 The list is not exhaustive; we only provide examples. 
Teachers should put emphasis on the listening comprehension and the practice of specific sounds which do not belong to the repertoire of sounds used in Polish. Such a training is especially useful with young learners, who are more capable of differentiating and producing unfamiliar sounds that they hear, as compared with the older ones (Ausubel 1964). Thus, a teacher should speak exclusively or mainly in English and engage children in conversations, reciting, and singing, to facilitate proper accent acquisition through practice and appropriate exposure. A wider array of known sounds will allow students to communicate more fluently and avoid using similar Polish sounds in place of the English ones in the future.

\section{Comparison of orthography}

Polish and English differ in language transparency (orthographic consistency), a correspondence between letters and sounds, and regularity of the language formation rules. In transparent languages, e.g. Finnish, Spanish (Erickson, Sachse 2010), an almost oneto-one correspondence between phonemes and graphemes exists, while in opaque ones (e.g. English, French) the rules of grapheme pronunciation are ambiguous. Polish is semitransparent (Miles 2000).

English spelling is highly complicated and irregular, e.g. 'a' can be pronounced as 'cat' /kæt/, 'was'/wpz, wəz/, 'saw'/so:/, 'made'/merd/, 'car' /ka:(r)/ (Ziegler, Goswami 2006), silent letters occur. Numerous homonyms can be: identical in the spoken and written form, homophones, and. homographs. Some foreign words kept the original spelling, e.g. 'fjord', 'café'. Nijakowska (2010) lists the following as the most difficult for English as L2 learners: 1) one sound may be graphically represented by different letters; 2) one sound may be graphically represented by different letters or their combinations in different words, 3) one letter or their combination may represent more than one sound, 4) numerous exceptions and irregularities.

Polish spelling is based on 4 rules (Gajda 1999):

1) phonetic - spelling concordant with pronunciation, where each sound is represented by a particular letter; most words in Polish follow this rule, e.g. 'dom' ('house');

2) morphological - homogeneous spelling of prefixes and suffixes, notwithstanding their pronunciation, which changes due to assimilation or simplification, e.g. 'prośba' [proźba] ('request');

3) historical - spelling of pairs of letters (with identical pronunciation): ó $+u, r z+\dot{z}$, $\mathrm{ch}+\mathrm{h}$, based on the historic processes of language development;

4) conventional - applied when pronunciation, morphology and history cannot explain the correct spelling, e.g. the particle 'nie'.

Due to the fact that English and Polish orthography differ to such an extent, teachers of English should indicate that the pronunciation of a word is frequently not concordant with its spelling, e.g. due to irregularities, silent letters, etc. Sight vocabulary lists could be applied to teach basic vocabulary using a holistic, not an analytic-synthetic method, which is more suitable for the specifics of English orthography. 


\section{Linguistic transfer}

Multilingualism is the ability to use regularly more than one language in everyday life (EC 2007). Competence level in L2 does not need to resemble a native speaker's one in proficiency to call a user bilingual. Weinreich (1968) lists 3 kinds of biligualism: 1) a word and its counterpart are completely separate in two language systems, 2) a word and its counterpart are separate in two language systems, but they share a meaning, 3) an L2 word is a translation of its L1 counterpart, which has a certain meaning. When learners use their L1 knowledge and experience to infer interlanguage rules, transfer errors occur (Zybert 1999), as certain patterns change due to the introduction of foreign elements to a structured language domain (Weinreich 1968). Transfer in SLA manifests in facilitation, avoidance, and over-use of certain structures (Zybert 1999). Odlin (1989) lists positive transfer, negative transfer (underproduction, overproduction, production errors, misinterpretation), and differing lengths of acquisition. He emphasises that transfer is not simply: a consequence of habit formation, interference (as ease of vocabulary learning depends of the number of L1-L2 cognates), falling back on L1, and not always the influence of L1 (as L2 influences L3). The bigger the difference between the languages, the bigger SLA difficulties and more numerous potential negative transfer areas.

\section{Typical difficulties in learning English by Polish students}

Polish learners of English as L2 encounter many difficulties, some of which might be, at least partially, explained by a negative linguistic transfer ${ }^{3}$. Such problems may concern all aspects of language:

1) syntax

a) disregard for the fixed word order, and word by word translations, *'In home is mom' ('W domu jest mama'), *'I very like strawberries' ('Ja bardzo lubię truskawki'), *'In London are' ... ('W Londynie są...'), or *'I always was going on beaches' ('Zawsze chodziłem/chodziłam na plażę');

b) no inversion to form questions, e.g. *’You know my sister?' ('Ty znasz moją siostrę?');

c) keeping inversion when not needed, e.g. *'Do you know where is the hospital?' ('Czy wiesz gdzie jest szpital');

d) wrong verb forms, e.g. *'I would like to found', *'I want to finished';

e) omitting conjunctions, *'a lot places' ('dużo miejsc');

2) morphology

a) faulty inflectional endings, *'He live in Poland', *'He don't like', *'Mens are brave', *'I going to', *I been in Spain', *'I've dreaming about', *'She go home yesterday', *'the Europe Union', *'He live's in London';

\footnotetext{
3 The categories have been mostly taken from Zybert (1999). All the provided examples come from Martyna Jaskulska's classroom experience as a teacher, or from data from a research project examining Polish students difficulties in learning English as L2 (cf. Łockiewicz, Jaskulska, 2016).
} 
b) overusage of the prefix -un, *'responsible'- 'unresponsible' or *'legal-unlegal'.

c) confusing grammatical categories, *'I did bad on the test' or *'I feel well' ('Czuję się dobrze');

d) copying Polish rules of concord into English, *'Your hairs are long' ('twoje włosy są długie');

e) countable/uncountable nouns, *'Her advices are really useful' ('jej rady są naprawdę przydatne'), *’Money are not important' ('pieniądze nie są ważne');

3) lexicon

a) omitting articles, *'dog'; *'in whole world', or adding them unnecessarily, *'a planes';

b) faulty homophones, *'My peace is small' instead of 'My room is small' ('pokój' is a Polish homophone for room and peace);

c) replacing English words with similar Polish real words, 'trening' for 'training', 'sens' for 'since', 'statua' for 'statue';

4) semantics

a) 'false friends', *'This novel is interesting' (instead of 'short story' - 'nowela'), *'This timetable is not actual' (instead of 'outdated' - 'nieaktualny'), or *'He is very sympathetic' (instead of 'nice' - 'sympatyczny');

5) phonetics/phonology

a) faulty analogies, pronouncing 'blood' as *[blud], instead of [bl $\Lambda \mathrm{d}]$, using anal-

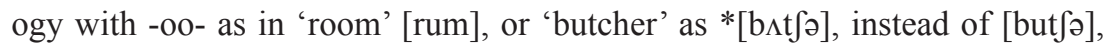
using analogy with -u- as in 'but' [bst];

b) pronouncing all letters in a word and/or replacing English sounds with similar Polish sounds, 'going' - *['gəoing], instead of ['gəoin], 'sad' *[sed] instead of [sæd];

6) orthographic/phonological errors (faulty words spelling)

a) using Polish orthography, *'enaf' ('enough'), *'et' ('ate'), *'syn's, * 'sins' (since'), *'Itali' ('Italy'), *'ofcourse' ('of course'), *'italian' ('Italian'), *'i' ('I');

b) using Polish letters to spell the English phonemes, assuming no difference in sound, *'strits' ('streets'), *'complit' ('complete'), *'surwive' ('survive'), *'wegetebuls' ('vegetables'), *'der' ('there'), sometimes arriving at correct in spelling, but not homophonic English words, e.g. *'bird' for 'beard', *'July' for 'jewel';

c) dropping silent letters, *'wail'/'weil'/'weyl' for 'whale', *'climat' for 'climate'; dropping double consonant spelling, *'polution' for 'pollution', *'swiming' for 'swimming', *'totaly' for 'totally', *'realy' for 'really', confusing similar sounding words, *'leaves' for 'lives', *'set' for 'said'.

d) All these problems may lead to serious misrepresentations of words, *'kamykulls' for 'chemicals', *'endzint' for 'engine', *'iglue' for 'igloo'.

The aforementioned errors were produced by high school students, and most of them in writing, which allows for a detailed content and structure analysis. However, they present patterns of errors typical for Polish learners at all ages, some of which may be 
prevented by certain educational methods applied in early education courses, when improper linguistic habits have not yet been automatised. Therefore, it is important that early education teachers are aware of these errors and adjust their teaching accordingly, as we propose in this paper.

\section{Discussion}

Odlin (1989) states that learners of different backgrounds make similar errors, which confirms that linguistic transfer belongs to many factors important in SLA. The meta-analysisby Melby-Lervåg and Lervåg (2011) demonstrated L1-L2 cross-linguistic transfer for oral language, decoding, and phonological awareness skills. Moreover, Lewandowska (2013) identified types of mistakes made by advanced Polish learners of English that could be wholly or partially explained by L1 influence: underdifferentiation (which appears when an L1 form has two counterparts in L2 that the learner fails to differentiate, e.g. 1. past tense in Polish vs. 1. Past Simple and 2. Present Perfect in English), calque, and feature absent from L1 (a lexical or morphological element, a semantic distinction, a grammatical or syntactic rule). We noted all these types of mistakes in our students' written works. Lewandowska (2013) noticed L1 interference in all aspects of the written language in her data, from the most basic ones (e.g. grapho-phonemic errors) to the more complex ones (e.g. clause combining errors).

Unfortunately, textbooks usually fail to include comparisons between L1 and L2, while educational grammar should be comparative-contrastive in order for the teacher to be able to build L2 competence using L1 competence, and enhance positive transfer (Paradowski 2006). Teachers do not put enough emphasis on pronunciation drilling and unique English sounds. According to junior high-school students' assessment (GajewskaDyszkiewicz et al. 2012), even though a similar amount of time is devoted to vocabulary, grammar, pronunciation, and writing instruction, vocabulary teaching is a priority. Sometimes an English lesson is conducted partly, if not totally, in Polish, even though the more often the teacher speaks English in the classroom, the more often the students do the same.

Students can acquire L2 inflection knowledge, even if such inflection is not present in their L1 (Song 2015). We believe that similar conclusion might be inferred about all language characteristics specific to any L2 or L3. To achieve that effect, effective SL education is crucial. Lewandowska (2013) suggests that teachers should focus on types of students' SLA problems connected to the linguistic transfer, to prevent incorrect linguistic habits and increase accuracy. This matches Odlin's (1989: 4) remark that: "Teaching may become more effective through a consideration of differences between languages and between cultures", as the awareness of the linguistic transfer might help the teachers to expect and predict certain types of errors to be produced by their students, which would facilitate the selection and development of effective instruction methods and techniques. 


\section{Conclusions}

A beneficial impact of an earlier exposure to English, either formal or informal, is visible as late as college education (Al-Qahtani, 2013). For teachers, errors indicate both progress, as they prove that learning occurs (Selinker 1992), and lacks in knowledge. For learners, they inform about strengths and weaknesses. For researchers, errors reveal how languages are learnt and which instruction and learning methods are effective. Having in mind the typical structure of errors commited by Polish students of English on all stages of education, the teachers in early education courses should put emphasis on preventing certain incorrect linguistic habits. As coursebooks usually are not specifically designed to consider differences between certain languages, additional exercises should be prepared, that would focus on the specificity of Polish as compared to English. As children are less self-conscious about their communication in L2 attempts as compared with older learners (Ausubel 1964), teaching could be based on oral exercises, e.g. nursery rhymes, and real communications, e.g. using a dialogic teaching approach (Alexander, 2010). The acquisition of proper linguistic habits in young learners would equip them with invaluable skills for their later formal and informal SL education.

\section{Acknowledgements}

We thank Dorota Wieczorek, Aleksandra Mielnik, and Renata Jażdżewska for their help in data collection. Thanks are also due to Prof. Danuta Stanulewicz for her remarks and consultation. The authors were awarded a grant for the project from the University of Gdansk, registration number: 538-7416-B128-13, in 2013.

\section{References}

Al-Qahtani M.F. (2013), Relationship between English Language, Learning Strategies, Attitudes, Motivation, and Students' Academic Achievement. "Education in Medicine Journal", 5(3).

Alexander R. (2010), Speaking but not listening? Accountable talk in an unaccountable context. "Literacy", 44(3), doi:10.1111/j.1741-4369.2010.00562.x

Ausubel D.P. (1964), Adults versus Children in Second-Language Learning: Psychological Considerations. "Modern Language Journal", 48 (7).

Cummins J. (1991), Interdependence of First- and Second-Language Proficiency in Bilingual Children. In: E. Bialystok (ed.). Language Processing in Bilingual Children. Cambridge, Cambridge University Press.

Doroszewski W., Wieczorkiewicz B. (1972), (eds). Fonetyka. Części Mowy. Stowotwórstwo. Warszawa, Państwowe Zakłady Wydawnictw Szkolnych.

Dz.U. (Journal of Legislation of the Republic of Poland) of 2014, item 803.

EC (2007). Commission of European Communities, Final Report, High Level group on Multilingualism. Luxembourg. 
Erickson K., Sachse S. (2010), Reading Acquisition, AAC and the Transferability of English Research to Languages with More Consistent or Transparent Orthographies. "Augmentative and Alternative Communication", 26 (3).

Eurydice (2005), Key data on teaching languages at school in Europe. Brussels, European Commission.

Forel C.A., Puskas G. (2005), Phonetics and Phonology. Reader for First Year English Linguistics. Geneva, University of Geneva

Fromkin V., Rodman R. (1993), An Introduction to Language. Philadelphia, Harcourt Bruce College Publishers.

Gajewska-Dyszkiewicz A. et al. (2012), Lekcja języka angielskiego z perspektywy uczniów klas trzecich gimnazjów. "Edukacja”, 3 (119).

Gajda S. (1999), O językowym planie wyrażania, czyli o... Logopedia. Pytania I Odpowiedzi. Podręcznik Akademicki. Eds. Gałkowski, Tadeusz and Grażyna Jastrzębowska. Opole, Uniwersytet Opolski.

Komorowska H. (2009), Metodyka nauczania języków obcych. Warszawa, Fraszka Edukacyjna

Lewandowska A. (2013), The Effectiveness of Data-Driven Learning Techniques in Eliminating Polish Advanced EFL Learners' Interference Errors. Unpublished Doctoral Dissertation. Poznań, Uniwersytet im. Adama Mickiewicza w Poznaniu.

Łockiewicz M., Jaskulska M. (2016), Difficulties of Polish students with dyslexia in reading and spelling in English as L2. Learning and Individual Differences, 51, doi: 10.1016/j.lindif.2016.08.037.

Malczewski J. (1990), Nauka O Języku. Słownik szkolny. Warszawa, Wydawnictwa Szkolne i Pedagogiczne.

Melby-Lervåg M., Lervåg A. (2011), Cross-Linguistic Transfer of Oral Language, Decoding, Phonological Awareness and Reading Comprehension: A Meta-Analysis of the Correlational Evidence. "Journal of Research in Reading", 34 (1).

Miles E. (2000), Dyslexia May Show a Different Face in Different Languages. "Dyslexia", 6 (3).

Milewski S. (1999), Lingwistyczne i dydaktyczne aspekty analizy fonemowej. Lublin, Wydawnictwo Uniwersytetu Marii Curie-Skłodowskiej.

Nijakowska J. (2010), Dyslexia in the Foreign Language Classroom. Bristol, St. Nicholas House.

Odlin T. (1989), Language Transfer: Cross-Linguistic Influence in Language Learning. Cambridge, Cambridge University Press.

Paradowski M.B. (2006), Uczyć, aby nauczyć - rola języka ojczystego w gramatyce pedagogicznej i implikacje dla dydaktyki języków obcych. W: J. Krieger-Knieja, U. Paprocka-Piotrowska (eds.). Komunikacja językowa w społeczeństwie informacyjnym - nowe wyzwania dla dydaktyki języków obcych. Lublin, Towarzystwo Naukowe KUL.

Porayski-Pomsta J., Podracki J. (1996), Nasz Ojczysty Język. Gramatyka, Ortografia i Interpunkcja. Warszawa, Wydawnictwo Oświata.

Ryndak L. (2014), The International and Slavonic Phonetic Alphabets. "Beyond Philology", 11.

Selinker L. (1992), Rediscovering Interlanguage. London, Longman.

Song Y. (2015), L2 Processing of Plural Inflection in English. "Language Learning”, 65 (2).

Tokarski J. (1978), Fleksja Polska. Warszawa, PWN.

Weinreich U. (1968), Languages in contact. Findings and problems. The Hague, Mouton Publishers.

Ziegler J.C., Goswami U. (2006), Becoming Literate in Different Languages: Similar Problems, Different Solutions. "Developmental Science", 9 (5). 